Situs Jurnal : $\underline{\text { http://ejournal.stiepancasetia.ac.id/index.php/iieb }}$

Jilid 6 Nomor 2 Juli 2020

Hal 238 - 244

\title{
KEARIFAN LOKAL DALAM LINGKUNGAN SEKOLAH DASAR SEBAGAI BENTENG ARUS NEGATIF MEDIA INFORMASI PADA SEKOLAH DASAR ISLAM TERPADU DI BANJARMASIN
}

\author{
Marliza Noor Hayatie*, Rabiaty Diana. S*, Tina Lestari *
}

\begin{abstract}
Education is an effort to develop students' potential in order to realize an atmosphere of learning and teaching and learning process to be active. Therefore, students can have spiritual strength, self-control, personality, intelligence, noble character, and the skills needed by the current environment. Education that utilizes lokal strengths in all aspects for the development of student competencies is a concept of education based on lokal wisdom. This research belongs to qualitative research. The population in this study was SDIT Al Firdaus, SDIT Anak Sholeh Mandiri and SDIT Permata Jannati. Based on the discussion of local wisdom in the elementary school environment as a fortification of negative flow of information media at SDIT in Banjarmasin, it can be concluded that: (1) there was an application of local wisdom in the Integrated Islamic Elementary Schools environment, (2) there was a strengthening of religious values in fortifying negative currents information media.
\end{abstract}

Keywords: local wisdom, elementary school students, information media

Abstrak: Pendidikan adalah usaha untuk membuat siswa agar dapat mewujudkan situasi belajar serta proses belajar mengajar menjadi aktif dengan mengembangkan potensi yang ada pada siswa. Sehingga siswa dapat memiliki kekuatan spiritual keagamaan, pengendalian diri, kepribadian, kecerdasan, akhlak mulia, serta ket-erampilan yang dibutuhkan lingkungan saat ini. Pendidikan yang memanfaatkan kekuatan lokal dalam segala aspek demi perkembangan kompetensi siswa merupakan konsep pendidikan berbasis kearifan lokal. Jenis data kualitatif merupakan jenis data yang diperlukan dalam melakukan penelitian ini. Populasi dalam penelitian ini adalah SDIT Al Firdaus, SDIT Anak Sholeh Mandiri dan SDIT Permata Jannati. Berdasarkan pembahasan tentang kearifan lokal dalam lingkungan sekolah dasar sebagai benteng arus negatif media informasi pada SDIT di Banjarmasin, maka dapat disimpulkan bahwa: (1) Adanya penerapan kearifan lokal dalam lingkungan sekolah dasar islam terpadu, (2) Melakukan penguatan nilai keagamaan dalam membentengi arus negatif media informasi.

Kata kunci: kearifan lokal, siswa sekolah dasar, media informasi

\section{Latar Belakang}

Pada era globalisasi saat ini, media sosial menjadi alat komunikasi yang dapat membuat masyarakat menjadi lebih mudah untuk melakukan berbagai interaksi dengan seluruh orang di mana saja. Masyarakat juga dapat lebih mudah dalam memperoleh berbagai informasi melalui media sosial tanpa batas. Media sosial juga sering digunakan oleh anak-anak sehingga bisa berdampak positif dan juga negatif terhadap pembentukan karakter anak. Media sosial yang banyak dipakai oleh anak-anak adalah google, youtube, game online, tiktok, dan masih banyak lagi.

Begitu banyak dampak positif yang didapatkan saat kita bisa dengan bijak memanfaatkan media informasi yang tersaji saat ini. Namun, jika media informasi tersebut dihadapkan pada anak yang masih 
belum bisa memilih dengan bijak informasi-informasi yang tersaji di dunia maya maka akan sangat banyak dampak negatif yang akan mempengaruhi karakter anak. Sehingga saat ini sangat dibutuhkan penguatan karakter anak dengan memberikan pembelajaran dengan kearifan lokal. Karena dengan memberikan penguatan karakter terhadap anak melalui kearifan lokal dapat membentengi berbagai dampak negatif dari media informasi tersebut.

Pendidikan adalah usaha untuk membuat siswa agar dapat mewujudkan situasi belajar serta proses belajar mengajar menjadi aktif dengan mengembangkan potensi yang ada pada siswa. Sehingga siswa dapat memiliki kekuatan spiritual keagamaan, pengendalian diri, kepribadian, kecerdasan, akhlak mulia, serta keterampilan yang dibutuhkan lingkungan saat ini (Sagala, 2011).

Mampu mengembangkan generasi muda sehingga menjadi pribadi yang dewasa dan berbudaya merupakan salah satu tugas pendidikan (Pidarta, 2009). Sedangkan kebudayaan nasional berasal dari kebudayaan daerah, sehingga sudah sepantasnya fungsi ilmu pengetahuan dalam dunia pendidikan dapat mengembangkan kearifan lokal. Dan melalui proses pendidikan diinginkan agar siswa memiliki keterampilah untuk bertahan hidup dan karakter agar dapat beradaptasi dengan zaman yang selalu berkembang tanpa menyampingkan ke-budayaan daerah.

Pendidikan yang memanfaatkan kekuatan lokal dalam segala aspek demi perkembangan kompetensi siswa merupakan konsep pendidikan berbasis kearifan lokal (Asmani, 2012). Menurut (Faturrahman; Ahmadi, 2012) budaya yang dapat membuat pertumbuhan dan perkembangan siswa, diawali dengan budaya lingkungan terdekat yang kemudian berkembang ke budaya nasional bangsa serta budaya universal yang menjadi pandangan hidup seluruh penduduk dunia.
Pendidikan yang dimaksud adalah pendidikan yang berdasarkan nilai-nilai hidup dapat tercermin dalam nilai agama Islam, yakni sebagai usaha sadar dalam suatu kegiatan bimbingan, pengajaran dan latihan untuk meningkatkan keyakinan, pemahaman, penghayatan dan pengamalan ajaran agama Islam dari peserta didik yang di samping untuk membentuk kesalehan atau kualitas pribadi juga sekaligus untuk membentuk kesalehan sosial. Dalam arti kualitas atau kesalehan pribadi itu diharapkan mampu memancar ke luar dalam hubungan keseharian dengan manusia lainnya (bermasyarakat), baik yang seagama (sesama muslim) ataupun yang tidak seagama (hubungan non muslim), serta dalam berbangsa dan bernegara sehingga terwujud persatuan dan kesatuan nasional dan bahkan persatuan dan kesatuan antarsesama manusia (Muhaimin, 2012)

Dengan semakin pesatnya perkembangan teknologi informasi di era globalisasi saat ini, dunia pendidikan tidak dapat menghindari pengaruh nya terhadap siswa. Dimana dunia pendidikan diharuskan untuk mengikuti perkembangan teknologi informasi agar dapat meningkatkan mutu pendidikan, terutama menyesuaikan teknologi informasi dan komunikasi yang digunakan dalam kegiatan pembelajaran.

Menurut (Uno, Hamzah B; Lamatenggo, 2010) kecenderungan pendidikan di Indonesia dimasa depan selanjutnya adalah sebagai berikut :

1. Semakin berkembangnya metode pembelajaran dengan daring.

2. Pertukaran instrument pendidikan antar institusi pendidikan/ latihan.

3. Semakin seringnya penggunaan berbagai perangkat berbasis teknologi pada dunia pendidikan.

Pendidikan agama merupakan sarana transformasi pengetahuan dalam aspek keagamaan, pembentukan sikap, pengendalian perilaku sehingga 
terbentuknya kepribadian yang baik. Sehingga dengan memberikan Pendidikan agama islam diharapkan dapat mewujudkan anak yang mampu menghadapi berbagai dampak negatif dari media informasi.

Berdasarkan uraian di atas, maka menjadi tantangan sekaligus peluang dalam dunia

pendidikan Islam sebagai wadah pembentukan manusia Indonesia yang siap menghadapi

rintangan sekaligus menciptakan anak bangsa yang tetap kokoh mempertahankan Negara

Kesatuan Republiik Indonesia. Karena itu dalam tulisan makalah ini akan memaparkan

proses implementasi kearifan lokal dalam lingkungan sekolah sebagai benteng untuk menghadapi arus negatif media informasi pada Sekolah Dasat Islam Terpadu di Kota Banjarmasin.

\section{Kajian Literatur}

1. Pendidikan Berbasis Kearifan Lokal

Kearifan lokal adalah jati diri dari budaya sebuah bangsa yang mengakibatkan bangsa tersebut dapat meresapi, bahkan dapat membuat kebudayaan bangsa lain menjadi karakter dan kompetensi sendiri (Wibowo, 2015).

Kearifan lokal dapat didefinisikan sebagai kebijaksanaan atau nilainilai luhur yang terkandung dalam kekayaankekayaan budaya lokal berupa tradisi, petatah-petitih dan semboyan hidup. Berbicara kearifan lokal berarti membicarakan budaya dan kebudayaan sebagai hasil dari cipta manusia. Karena kearifan lokal yang dianut oleh masyarakat setempat bermula dari tradisi yang membudaya. Masa kini dan masa depan tidak dapat dilepaskan dari apa yang dilakukan masyarakat di masa lalu. Maka budaya sebagai warisan masa lalu harus dijaga, dihormati dan dilestarikan di masa kini ( Syarifah, 2018).
Pendidikan berbasis kearifan lokal adalah pendidikan yang memberikan pengajaran kepada siswa didik untuk selalu terikat dengan kenyataan yang mereka hadapi. Menurut Paulo Freire (Wagiran, 2010) dengan adanya masalah dan kenyataan yang dihadapi, siswa akan semakin termotivasi untuk merespon secara kritis. Sehingga sesuai dengan pilar pendidikan yang disampaikan oleh (Suwito, 2008):

1) menjadikan seseorang berpendidikan harus berlandaskan pada pengakuan eksistensi manusia sejak dalam kandungan,

2) pendidikan harus berbasis kebenaran dan keluhuran budi, menjauhkan dari cara berpikir tidak benar dan grusagrusu atau waton sulaya,

3) pendidikan harus mengembangkan ranah moral, spiritual (ranah afektif) bukan sekedar kognitif dan ranah psikomotorik, dan

4) sinergitas budaya, pendidikan dan pariwisata perlu dikembangkan secara sinergis dalam pendidikan yang berkarakter.

Menurut (Surasmi, 2012) pendidikan berbasis kearifan lokal untuk membangun moral bangsa, adalah kearifan dan bermacam nilai serta budaya masyarakat.

Sehingga dapat disimpulkan pendidikan berbasis kearifan lokal merupakan penyajian proses belajar mengajar yang memberikan perspektif hidup, ilmu pengetahuan, dan bermacam-macam strategi kehidupan dalam bentuk kegiatan yang dikerjakan oleh masyarakat disekitar untuk menghadapi berbagai masalah dalam memebuhi kebutuhan.

2. Dampak Media Informasi Terhadap Anak

a. Dampak Positif

Menurut (Khadza, 2013) media sosial memiliki kelebihan diantaranya adalah : 
1) Di era digital saat ini, perkembangan kreativitas anak semakin baik.

2) Anak dapat memperbanyak teman

3) Dapat memotivasi anak untuk menambah wawasan melalui teman yang mereka temui di media sosial

4) Anak menjadi lebih peka terhadap stuasi dan kondisi.

5) Anak dapat membangun jaringan dengan orang lain dari berbagai negara.

6) Anak bisa mendapatkan informasi dengan cepat dan murah dari berbagai negara.

b. Dampak Negatif

Menurut (Khadza, 2013) dampak negatif diantaranya adalah :

1) Intensitas waktu anak untuk berkomunikasi dalam dunia nyata menjadi berkurang.

2) Anak menjadi lebih egois, tidak terbuka dan tidak perduli dengan orang lain disekitarnya.

3) Sopan santun anak dalam berkomunikasi semakin berkurang karena mereka sukar untuk membedakan antara komunikasi formal dan in-formal.

4) Menjadi tempat yang aman untuk melakukan kejahatan karena situs jejaring sosial sulit untuk dilacak.

5) Banyaknya ditemukan gambar ataupun video yang bermuatan negatif seperti pornografi dan kekerasan sehingga berpeluang untuk meningkatkan tindakan criminal di jejaring sosial.

6) Penipuan: Di jejaring sosial, jati diri yang ditampilkan tidak sepenuhnya benar sehingga tindakan penipuan semakin mudah dilakukan seseorang.

7) Perjudian : Akses pertemanan di media sosial dapat membentuk arena perjudian secara maya yang kemudian menjadi nyata disebabkan tersedianya akses untuk berjudi di dunia maya yang kemudian ditindak lanjuti pada kehidupan sesungguhnya.

\section{Arti Pendidikan Karakter Islami Berbasis} Nilai-Nilai Kearifan Lokal

Secara istilah, karakter diartikan sebagai sifat manusia pada umumnya, dimana manusia mempunyai banyak sifat yang tergantung dari faktor kehidupannya sendiri. Karakter adalah sifat kejiwaan, akhlak atau budi pekerti yang menjadi ciri khas seseorang atau sekelompok orang (Majid \& Andayani, 2010). Dengan demikian, karakter dapat juga diartikan sama dengan akhlak, yaitu keadaan jiwa seseorang yang mendorong untuk melakukan perbuatan-perbuatan tanpa melalui pertimbangan pemikiran terlebih dahulu. Hal itu sebagaimana pendapat Ahmad Tafsir (Hasanah, 2013) bahwa karakter merupakan perilaku yang dilakukan secara otomatis dan artinya semakna dengan pengertian akhlak yang dikemukan oleh Ibn Maskawaih dan al-Ghazali.

Karakter itu berkaitan dengan kekuatan moral yang positif, dan bukan konotasi negatif. Dan orang berkarakter adalah orang yang mempunyai kualitas moral yang positif. Dengan demikian, pendidikan adalah membangun karakter, yang secara implisit mengandung arti membangun sifat atau pola perilaku yang didasari atau berkaitan dengan dimensi moral yang positif saja (Salsabilah, 2019).

Secara akademis, pendidikan karakter dimaknai sebagai kesamaan pendidikan nilai, pendidikan budi pekerti, pendidikan moral, Pendidikan watak, atau pendidikan akhlak yang tujuannya mengembangkan kemampuan peserta didik untuk memberikan keputusan baikburuk, memelihara apa yang baik itu, dan mewujudkan kebaikan itu dalam 
kehidupan sehari-hari dengan sepenuh hati. Oleh karena itu pendidikan karakter secara lebih luas dapat diartikan sebagai pendidikan yang mengembangkan nilai budaya dan karakter bangsa pada diri peserta didik sehingga mereka memiliki nilai dan karakter sebagai karakter dirinya, menerapkan nilai-nilai tersebut dalam kehidupan dirinya sebagai anggota masyarakat, dan warga negara yang religius, nasionalis, produktif, dan kreatif (Ainiyah, 2013).

\section{Metode Penelitian}

Metode penelitian yang dipilih dalam penelitian ini adalah pendekatan kualitatif yang bertujuan untuk menggambarkan, mengungkap, menjelaskan dan menganalisis terhadap konsep dan praktek pendidikan karakter islami berbasis nilainilai kearifan lokal di SDIT Banjarmasin. Data kualitatif diperoleh melalui pelaksanaan observasi langsung kelapangan sehingga dapat mengamati dan mencatat berbagai fenomena yang memberikan dukungan terhadap bahan untuk menganalisa data dan informasi yang ditemukan.

Populasi dalam penelitian ini sebanyak 3 (tiga) sekolah dasar islam terpadu, yaitu SDIT Anak Sholeh Mandiri, SDIT Al Firdaus, dan SDIT Permata Jannati. Sampel merupakan bagian yang diambil dari populasi (Sudjana, 2005). Sedangkan menurut (Sugiono, 2008) bagian dari jumlah dan karateristik yang dimiliki oleh populasi disebut sampel. Karena jumlah populasi pada penelitian ini yang tidak terlalu banyak, maka teknik sampling yang digunakan adalah snowball sampling. Teknik ini digunakan untuk mengidentifikasi, memilih dan mengambil sampel dalam suatu jaringan atau rantai hubungan yang menerus. Dengan demikian diperoleh sampel sebanyak 60 orang yaitu perwakilan 10 siswa setiap kelas IV dan V SDIT Al Firdaus, dan IV dan V SDIT Anak Sholeh Mandiri dan IV dan V SDIT Permata Jannati.
Dalam penelitian ini digunakan metode pengumpulan data sebagai berikut:

1. Metode observasi

Metode observasi yaitu pengumpulan data yang dilakukan secara sistematis dan disadari, dimulai dengan mengadakan pengamatan dan pencatatan atas indikator yang su-dah diteliti dengan melibatkan diri dalam latar yang sedang diteliti (Arifin, 1996). Penelitian menggunakan metode observasi untuk mengetahui secara langsung bagaimana penerapan kearifan lokal pada sekolah dasar yang melingkupi, SDIT Al Firdaus, SDIT Anak Sholeh Mandiri dan SDIT Permata Jannati.

2. Metode wawancara

Metode ini mencakup cara yang dipergunakan untuk mendapatkan keterangan atau pendapat secara lisan langsung dari seseorang atau informan. Sesuai dengan rencana yang digunakan dalam penelitian ini yaitu studi kasus, maka pedoman wawancara tidak terstruktur, yaitu pedoman wawancara yang hanya memuat garis besar yang diwawancarai. Dengan wawancara ini kreatifitas pewawancara sangat diperlukan. Hasil wawancara banyak bergantung pada pewawancara.

3. Metode dokumentasi

Metode dokumentasi adalah suatu teknik yang digunakan untuk mengumpulkan data, terdiri dari dokumen dan rekaman seperti surat kabar, buku harian, naskah pribadi, foto-foto, catatan kasus, dan lain sebagainya (Arifin, 1996).

\section{Hasil Penelitian}

\section{Penerapan Kearifan Lokal Dalam Lingkungan Sekolah Dasar Islam Terpadu}

Berdasarkan penelitian yang dilakukan di SDIT Al-Firdaus, SDIT Anak Sholeh Mandiri dan SDIT Permata Jannati, maka terdapat berbagai kegiatan kearifan lokal yang sudah diterapkan oleh pihak sekolah kepada para siswa nya yang sejalan 
dengan nilai keagamaan. Nilai keagamaan yang diterapkan melalui membiasakan, memberikan pengajaran ataupun memberikan teladan kepada siswanya terlihat pada kegiatan yang dilaksanakan di sekolah tersebut, yaitu :

1. Kegitan harian sekolah yaitu berdoa dan berdzikir, tahfidz qur'an, mengaji, sholat dhuha berjamaah, sholat zuhur berjamaah, sholat ashar berjamaah, sholat sunnat rawatib.

2. Kegiatan mingguan sekolah yaitu berpuasa dan bersedekah, yang mana kegiatan dengan kearifan lokal tersebut dapat melatih kesabaran dan kepedulian anak terhadap sesama dan lingkungan di sekitar.

3. Kegiatan bulanan dan tahunan yang diadakan oleh sekolah adalah Malam Bina Iman dan Taqwa (MABIT) dan bakti sosial, dimana kegiatan atan dengan kearifan lokal ini dapat membentuk kepribadian dan mental anak menjadi mandiri, berakhlak, dan juga tangguh dalam menghadapi berbagai masalah.

\section{Penguatan Nilai Keagamaan Dalam Membentengi Arus Negatif Media Informasi}

Dari kegiatan membiasakan, memberikan pengajaran ataupun memberikan teladan di SDIT Al-Firdaus, SDIT Anak Sholeh Mandiri dan SDIT Permata Jannati, nilai keagamaan yang diterapkan untuk membentengi arus negatif media informasi anak didiknya adalah :

1. Nilai keimanan

Pendidikan keimanan adalah bahagian integral dari pendidikan Islam, baik dilihat dari konsep tujuan maupun aspek-aspek pembinaan dalam Pendidikan Islam. Berarti orientasi pendidikan Islam diarahkan untuk membina pribadi muslim seutuhnya sesuai dengan cita-cita Islam.

Kegiatan yang dilaksanakan di sekolah melalui kearifan lokal adalah dengan membiasakan anak untuk berdoa dan berdzikir, sholat berjamaah, sholat sunnat rawatib. Nilai keimanan yang diwujudkan dari perilaku anak didik adalah mencintai Allah, mencintai Rasul dan mengimani hari akhir.

2. Nilai Ibadah

Tata cara beribadah sebaiknya dibiasakan sejak dini pada anak didik. Ini dikarenakan siswa nantinya akan tumbuh menjadi manusia yang taat dalam melakukan semua kewajiban yang dianjurkan dalam agama dan juga taat k tidak melakukan semua larangan agama. Ibadah harus dilaksanakan secara konsisten dan baik oleh setiap anak didik.

Nilai ibadah dari kegiatan dengan kearifan lokal dapat dilihat dari kedisiplinan ibadah anak didik dalam melaksanakan ibadah wajib dan sunah, menyukai kegiatan membaca AlQur'an.

3. Nilai Akhlak

Nilai akhlak dari kegiatan dengan kearifan lokal dapat dilihat dari membudayakan sikap tawadhu' di sekolah, mandiri, bertanggung jawab, perduli terhadap sesama di lingkungan sekitar.

\section{Kesimpulan dan Keterbatasan Penelitian}

Berdasarkan pembahasan tentang kearifan lokal dalam lingkungan sekolah dasar sebagai benteng arus negatif media informasi pada SDIT Al-Firdaus, SDT Anak Sholeh Mandiri dan SDIT Permata Jannati, maka dapat disimpulkan bahwa :

1. Penerapan kearifan lokal dalam lingkungan sekolah dasar islam terpadu tercermin dari kegiatan harian, mingguan, bulanan dan tahunan yang telah dilaksanakan di sekolah. Kegiatannya berupa berdoa dan berdzikir, tahfidz qur'an, mengaji, sholat dhuha berjamaah, sholat zuhur berjamaah, sholat ashar berjamaah, sholat sunnat rawatib, berpuasa dan 
bersedekah, Malam Bina Iman dan Taqwa (MABIT) dan bakti sosial.

2. Melakukan penguatan nilai keagamaan dalam membentengi arus negatif media informasi terlihat dari terwujudnya perilaku anak didik adalah mencintai Allah, mencintai Rasul dan mengimani hari akhir, kedisiplinan ibadah anak didik dalam melaksanakan ibadah wajib dan sunah, menyukai kegiatan membaca Al- Qur'an, serta membudayakan sikap tawadhu' di sekolah, mandiri, bertanggung jawab, perduli terhadap sesama di lingkungan sekitar.

Dalam pelaksanaannya di lapangan, ada terjadi beberapa kendala. Oleh karena itu, perlu dilakukan upaya mencegah siswa berperilaku negatif yang dapat menghambat keberhasilan akademik. Upaya lainnya yang dilakukan adalah dengan memperkuat ideology dan nasionalis melalui berbagai kegiatan yang positif di lingkungan sekolah.

\section{DAFTAR PUSTAKA}

Aan Hasanah. (2013). Pendidikan Karakter Berperspektif Islam, Bandung: Insan Komunika

Abdul Majid dan Dian Andayani. (2010). Pendidikan karakter Berperspektif Islam, Bandung: Insan Cita Utama

Ainiyah Nur. (2013). Pembentukan Karakter Melalui Pendidikan Agama Islam. Jurnal Al-Ulum Vol. 13 No. 1.

Arifin, I. (1996). Penelitian kualitatif dalam ilmu-ilmu sosial dan keagamaan. Yogyakarta: Kalimasada Press.

Asmani, J. M. (2012). Tips sakti membangun organisasi sekolah. Yogyakarta: Diva Press.

Faturrahman; Ahmadi, K. (2012). Pengantar Pendidikan. Jakarta: PT. Prestasi Pustakaraya.

Khadza, F. L. (2013). Cara mudah mengenal dan membaca karakter dan kepribadian orang lewat Internet. Yogyakarta: Mantra Book.

Muhaimin. (2012). Paradigma Pendidikan Islam, Bandung: PT. Remaja Rosdakarya

Pidarta, M. (2009). Landasan Kependidikan (1st ed.). Jakarta: Rineka Cipta.

Sagala, S. (2011). Konsep dan makna pembelajaran untuk membantu memecahkan problematika belajar dan mengajar (1st ed.). Bandung: Alfabeta.

Salsabilah. (2019). Pendidikan Karakter Islami Berbasis Nilai-Nilai Kearifan Lokal. Jurnal Cendikia Vol. 17 No. 2.

Sudjana. (2005). Metoda Statistika. Bandung: Tarsito.

Sugiono. (2008). Statistik non parametris untuk penelitian. Bandung: Alfabeta.

Surasmi, W. A. (2012). Menggugah Kesadaran Guru dalam Kearifan Lokal pada Era Globalisasi. Surabaya: UPBJJ.

Suwito, Y. S. (2008). Pendidikan Berbasis Budaya Yogyakarta. Makalah Dalam Sarasehan Budaya Selasa Wagen Di Bangsal Kepatih, 15.

Syarifah, L (2018). Keselarasan Nilai Pendidikan Agama Islam Dengan Kearifan Lokal di SDIT. Wahana Islamika : Jurnal Studi Keislaman Vol .4 No. 2

Uno, Hamzah B; Lamatenggo, N. (2010). Teknologi komunikasi dan informasi pembelajaran. Jakarta: Bumi Aksara.

Wagiran. (2010). Pengembangan Model Pendidikan Kearifan Lokal di Wilayah Provinsi DIY dalam Mendukung Perwujudan Visi Pembangunan DIY menuju Tahun 2025 (Tahun Kedua). Biro Administrasi Pembangunan.

Wibowo, A. G. (2015). Pendidikan Karakter Berbasis Kearifan Lokal di Sekolah konsep, strategi, dan implementasi. Yogyakarta: Pustaka Pelajar. 